\title{
REVIEW
}

\section{The lentiginoses: cutaneous markers of systemic disease and a window to new aspects of tumourigenesis}

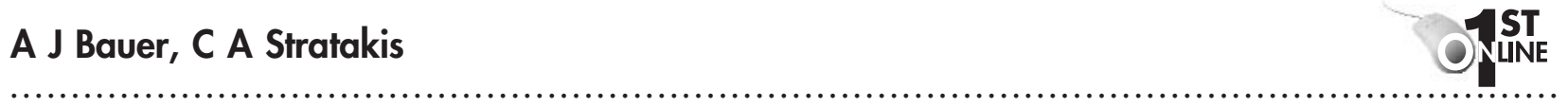

J Med Genet 2005;42:801-810. doi: 10.1136/jimg.2003.017806

Familial lentiginosis syndromes cover a wide phenotypic spectrum ranging from a benign inherited predisposition to develop cutaneous lentigines unassociated with systemic disease, to associations with several syndromes carrying increased risk of formation of hamartomas, hyperplasias, and other neoplasms. The molecular pathways involved in the aetiology of these syndromes have recently been more clearly defined and several major cellular signalling pathways are probably involved: the protein kinase A (PKA) pathway in Carney complex (CNC), the Ras/Erk MAP kinase pathway in LEOPARD/Noonan syndromes, and the mammalian target of rapamycin pathway (mTOR) in Peutz-Jeghers syndrome and the diseases caused by PTEN mutations. Here we discuss the clinical presentation of these disorders and discuss the molecular mechanisms involved. The presence of lentigines in these diseases caused by diverse molecular defects is probably more than an associated clinical feature and likely reflects cross talk and convergence of signalling pathways of central importance to embryogenesis, neural crest differentiation, and end-organ growth and function of a broad range of tissues including those of the endocrine, reproductive, gastrointestinal, cardiac, and integument systems.

See end of article for authors' affiliations

Correspondence to: Dr Constantine A Stratakis, Section on Endocrinology and Genetics, DEB NICHD, NIH, Building 10, CRC, Room I-3330, 10 Center Dr., MSC 1103 , Bethesda, MD 20892, USA; stratakc@mail.nih. gov

Revised version received 18 March 2005 Accepted for publication 21 March 2005 Published Online First 15 June 2005
T he medical examiner in rural Pennsylvania concluded "this combination of lesions is best explained by the concept of neurocristopathies" when finishing his report on the autopsy of a 19 year old heavily freckled man who died in 1981 due to malignant, metastatic (to his brain) pigmented melanotic schwannoma. The young man had been in and out of the National Institutes of Health (NIH) Clinical Center for a variety of ailments; he had first been diagnosed with a growth hormone producing tumour but his investigation and treatment was complicated by the baffling concurrent diagnosis of testicular tumours and hypercortisolaemia due to adrenal tumours. ${ }^{1}$ It was clear that he was affected simultaneously by two rare endocrine conditions, acromegaly and Cushing syndrome, and several physicians had noted his many "freckles" and other pigmented skin lesions, but his disease was not actually diagnosed until years later. In 1995, upon reviewing records of NIH patients, investigators came across his clinical description and it became obvious that he had Carney complex (CNC). CNC belongs to a group of disorders that are now slowly but surely being molecularly elucidated, the familial lentiginoses (table 1).

The lentiginoses share multiple lentigines as one of their most prominent clinical features, the lentigen being a hamartomatous melanocytic lesion of the skin clinically almost identical to a freckle but histologically quite distinct. ${ }^{2}$ PeutzJeghers syndrome (PJS) is the prototype of these diseases which are almost all inherited in an autosomal dominant manner, have a relatively high rate of de novo cases, and predispose to a variety of neoplasms. ${ }^{2}$ Laugier-Hunziker syndrome (LHS), arterial dissections with lentiginosis (ADL), centrofacial and partial unilateral lentiginoses, and LEOPARD and Noonan syndrome with lentigines (NSL) are other lentiginoses. ${ }^{2}$ A number of related disorders may be associated with lentigines: Ruvalcaba-MyhreSmith or Bannayan-Zonnana syndrome (RMS/ BZS), a condition allelic to Cowden disease (CD), ${ }^{3} \quad$ Schimke immunoosseous dysplasia, ${ }^{4}$ Mulvihill-Smith syndrome (MSS), ${ }^{5}$ Watson syndrome, ${ }^{6}$ McCune Albright syndrome (MAS), ${ }^{7}$ the two types of neurofibromatosis and other phacomatoses, $^{8}$ multiple endocrine neoplasia $2 \mathrm{~B}$ (MEN 2B), and nevus phacomatosus pigmentovascularis (NPP). ${ }^{9}$ Xeroderma pigmentosum may also be associated with solar lentigines; ${ }^{10}$ a number of chromosomal conditions and syndromes predisposing to premature aging or immunodeficiency or associated with DNA and/ or chromosomal repair defects may also present with lentigines. However, in most of these conditions, lentigines are either secondary or peripheral to the primary lesions and do not represent hamartomatous proliferation of the melanocytes as is the case in the familial lentiginoses. In this review, we focus on the latter, and among them, the syndromes that have been molecularly elucidated over the last decade: CNC, PJS/LHS, LEOPARD, and NSL and the conditions caused by PTEN mutations (RMS/ BZS and CD). The argument is made that the affected signalling pathways, protein kinase A (PKA), Ras/Erk MAP kinase, and the mammalian target of rapamycin (mTOR) converge to a complex system of cellular checks and balances that oversee growth, proliferation, and differentiation of many cell types; their perturbation causes a wide array of manifestations, including neoplasms that range from the simple lentigen to aggressive malignancies.

\section{LENTIGO}

Lentigines are often divided into two broad categories, simple lentigo and solar lentigo. 
Table 1 The main lentiginoses: clinical manifestations and genetics

\begin{tabular}{|c|c|c|c|c|c|}
\hline Disease & MIM & Clinical manifestations & Inheritance & Locus & Gene \\
\hline Carney complex & 160980 & $\begin{array}{l}\text { Lentigines, PPNAD cardiac and skin myxoma schwannomas, acromegaly, } \\
\text { breast and testicular tumours }\end{array}$ & $A D$ & $\begin{array}{l}17 q 22-24 \\
2 p 16\end{array}$ & $\begin{array}{l}\text { PRKAR1A (CNC2 } \\
\text { (CNC1) (?) }\end{array}$ \\
\hline Peutz-Jeghers & 175200 & Lentigines, GI polyps, neoplasia (GI tract, pancreas breast, ovary, uterus) & $A D$ & $19 p 13.319 q$ & LKB I/STKI 1 (?) \\
\hline LEOPARD & 151100 & $\begin{array}{l}\text { Lentigines, cardiac conduction abnormalities, aneurysms, pulmonic stenosis, } \\
\text { cephalo-facial dysmorphism, short stature, sensorineural deafness, mental } \\
\text { retardation, skeletal abnormalities }\end{array}$ & $A D$ & $12 q 22$-qter & PTPN11 \\
\hline $\mathrm{BRRS} / \mathrm{CD}$ & 153480 & $\begin{array}{l}\text { Macrocephaly, lipomatosis, pigmentation of the glans penis, mental } \\
\text { retardation, vascular malformations }\end{array}$ & $A D$ & $10 q 23$ & PTEN \\
\hline \multirow[t]{2}{*}{ Lentiginosis } & 151001 & Lentigines (centrofacial, palmoplantar, trunk) & $A D$ & Unknown & Unknown \\
\hline & 151000 & As above in addition to mental retardation, skeletal dysraphia & $A D /$ sporadic & Unknown & Unknown \\
\hline
\end{tabular}

Macules of café au lait colour that develop with older age are also called lentigo but they are clinically and genetically different lesions. In general, lentigines associated with the genetic diseases that are being discussed in this review develop at a young age, often increase in number during adolescence, and are not restricted to sun exposed areas, whereas solar lesions often develop after the third decade of life, increase with advancing age, and as the name implies, are found almost exclusively on sun exposed areas. ${ }^{11}{ }^{12}$ While the descriptive identification appears fairly straightforward, the clinical distinction of simple lentigo is at times more difficult, with lesions often confused with ephelides (freckles). However, several clinical features and histological differences do exist and should aid the clinician in separating these lesions. Although both types are of similar size and appearance and are often described as multiple 4-10 mm, variegated, brown to black macules, lentigines typically do not darken with sun exposure (as compared to ephelides) and may be distributed on distinct anatomic locations such as the face (around the eyes and on the eyelids, the saddle of the nose, and the perioral areas of the upper and lower lips, crossing the vermillion border in some diseases), palmoplantar regions of the hands and feet, breast nipples, buttocks and genital region (labial, vaginal mucosa, prepuce, and penile mucosa and skin), and less commonly other inner mucosal surfaces (buccal and anal mucosa, and/or the conjunctivae, especially the inner and outer canthal areas). ${ }^{2}{ }^{3}$ Histologically, while there is some overlap with freckles, lentigines show prominent rete ridges and melanocytic hyperplasia. In the case of ephelides and solar lentigines, increased pigmentation results from donation of pigment from otherwise normal (albeit stimulated) melanocytes to adjacent keratinocytes. $^{211}{ }^{12}$ Clinically, lesions on mucosal surfaces, in particular the lacrimal caruncle of the eye, and lesions that cross the vermilion border of the lips are of particular importance as pigmented lesions found in these locations are often heralding features of the familial lentiginosis syndromes that are associated with systemic disease.

\section{BENIGN LENTIGINOSES}

Centrofacial neurodysraphic (Mendelian Inheritance in Man (MIM) 151000) ${ }^{13}$ and patterned (MIM 151001) lentiginoses describe two inheritable conditions that, in keeping with all familial lentiginoses syndromes, follow autosomal dominant (AD) inheritance, but in contrast to the other members of this group are not associated with systemic disease. ${ }^{14} 15$ Touraine et al described the first syndrome, centrofacial neurodysraphic lentiginosis, reporting on a group of 32 patients from 17 families with early onset of facial lentigines, occasionally found on the upper lip, that faded over time, which was frequently associated with mental retardation. ${ }^{14}$ In 1989, O'Neil and James described inherited patterned lentiginosis: what distinguished this group of patients was the increased incidence in the African American population and the description of lentigines not only limited to the facial region but involving the hands, elbows, and buttocks as well. ${ }^{16}$ Interestingly, neither of these syndromes are associated with lesions of the oral mucosa. ${ }^{16}{ }^{17}$ Several other reports of multiple lentiginoses syndromes have since been published, but the significance of these syndromes, and potential overlap with other previously described syndromes, is as yet unknown. ${ }^{17} 18$

\section{CARNEY COMPLEX}

The association of myxomas, spotty skin pigmentation (lentigines), and endocrine overactivity was first reported by Dr J Aidan Carney in 1985 and subsequently designated as CNC by Bain in $1986^{19}$ and Carney syndrome by MIM $^{13}$ in 1994. With the report of this new syndrome it was realised that the majority of patients previously characterised under the separate diagnoses of LAMB (lentigines, atrial myxoma, mucocutaneous myxoma, blue nevi) and NAME (nevi, atrial myxoma, myxoid neurofibroma, ephelides) would now be more appropriately classified under CNC. The diagnosis of CNC is made if two of the main manifestations of the syndrome are present ${ }^{20}$; these need to be confirmed by histology, biochemical testing, or imaging. Alternatively, the diagnosis is made when one of the criteria is present and the patient is a carrier of a known inactivating mutation of the PRKARIA gene (see "Molecular mechanism" section below for discussion). ${ }^{20-22}$

The most common features of CNC include spotty skin pigmentation (fig l) (lentigines, freckling, café au lait spots, and blue nevi), myxomas of the heart, skin, and breast, and primary pigmented nodular adrenal cortical disease (PPNAD) associated with an atypical form of Cushing syndrome (CS). ${ }^{23}{ }^{25}$ The breadth of involved organs in CNC is quite unique; CNC is both a multiple endocrine neoplasia (MEN) (along with MEN-1 and -2) and a cardiocutaneous syndrome (along with LEOPARD and similar conditions). Of the noncutaneous lesions found in $\mathrm{CNC}$, cardiac myxomas are the most common. ${ }^{22}{ }^{24}$ These tumours tend to be of a more aggressive nature when compared to sporadic, non-CNCassociated myxomas: unlike the latter, the former may be in any cardiac chamber and may present multiple times, starting at a very young age (even in infancy) and without any predilection for gender (sporadic myxomas are more common in older women and almost always occur in the left atrium as single one-time tumours). ${ }^{22}$ Historically, cardiac myxomas have been reported to be responsible for more than $50 \%$ of the disease specific mortality among CNC patients. ${ }^{24}$

Endocrine gland involvement can result in growth hormone $(\mathrm{GH})$ secreting pituitary adenomas, thyroid gland disease, corticotropin (ACTH) independent CS secondary to PPNAD, and testicular tumours, in particular, large cell calcifying Sertoli cell tumours (LCCSCT). ${ }^{20-24}$ Overall, PPNAD is the most common endocrine lesion and causes the greatest degree of endocrine associated morbidity (discussed in more 

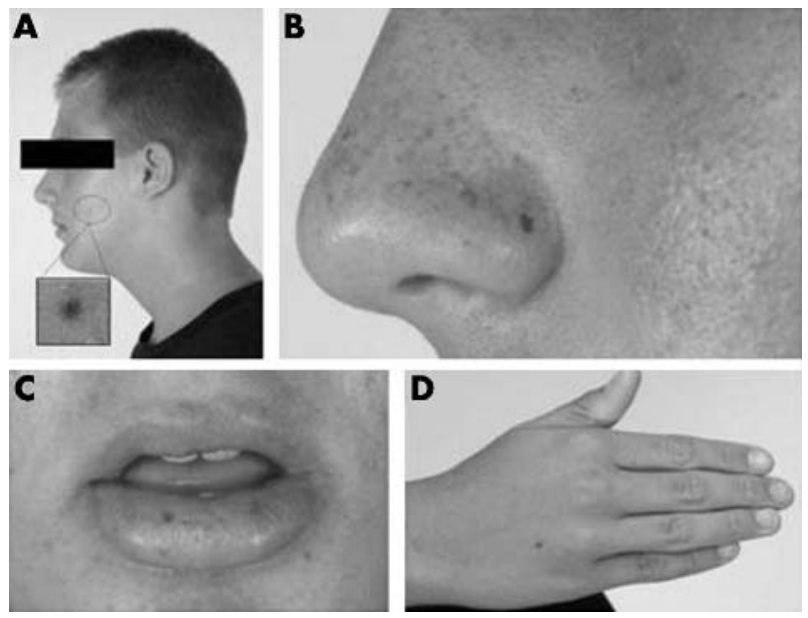

Figure 1 Pigmentation in Carney complex. (A) A blue nevus on the cheek of a patient with the complex. (B) Lentigines on the sides of the nose. (C) Lentigines on the vermillion border of the lips and the mucosa. (D) Blue nevus on the dorsal surface of the hand. Unusual pigmented lesions in patients with Carney complex may occur everywhere and are not unusual even in newborns with the disease. (These photographs are reproduced with consent.)

detail below). ${ }^{24}$ In male patients, however, the occurrence of LCCSCT may supersede PPNAD in number, but not in morbidity, as it is typically a benign lesion most often diagnosed during routine testicular ultrasound when microcalcifications are found. ${ }^{24}$ Leydig cell tumours and adrenal rests have also been reported..$^{24}$ Ovarian cysts are often found by sonographic examination as multiple hypoechoic lesions and although usually clinically insignificant, they may occasionally progress to ovarian carcinoma. ${ }^{20} 2627$

Thyroid gland disease spans the spectrum from nodular disease to carcinoma, but in contrast to pituitary and adrenal pathology, there does not appear to be an increased risk of hyper- or hypothyroidism. By sonographic examination, more than $60 \%$ of children and adults with CNC will be found to have cystic or multinodular disease. ${ }^{28}$ On biopsy, follicular adenoma is the most common finding, whereas thyroid cancer, follicular or papillary, may develop in up to $10 \%$ of CNC patients with preexisting thyroid pathology. ${ }^{28}$ Of note, recent examination for loss of heterozygosity $(\mathrm{LOH})$ at the CNC locus on chromosome $17(17 q 22-24)$ in sporadic thyroid cancer has found increased loss of this region, supporting the hypothesis that thyroid tissue is susceptible to tumourigenesis induced by PRKARIA loss of function. ${ }^{29}$

\section{Molecular mechanism}

Genetic linkage analysis has revealed two distinct loci for $\mathrm{CNC}$, one on chromosome 2pl6 (CNC2) and the other on chromosome 17q22-24 (CNC1)..$^{30}{ }^{31}$ Inactivating mutations of the gene encoding the protein kinase A type I- $\alpha$ regulatory $(\mathrm{Rl} \alpha)$ subunit (PRKARIA) were identified in patients mapping to chromosome 17 and analysis of 53 of the 70 kindreds registered in the National Institutes of Health-Mayo Clinic collection has revealed that 28 out of the $53(52.8 \%)$ have mutations at the $\mathrm{CNCl}$ locus. ${ }^{32}$ The gene responsible for $\mathrm{CNC}$ at the chromosome 2 pl6 locus is unknown and there is at least one large kindred with $\mathrm{CNC}$ that does not map to either the $\mathrm{CNCl}$ or $\mathrm{CNC2}$ locus. ${ }^{32}$ At this point, there are no clear phenotypic differences between families mapping to one or the other locus.

The role of $\mathrm{Rl} \alpha$ in human tumourigenesis has been explored in several different cancer tissues and cell lines. Enhanced expression of $\mathrm{R} l \alpha$ has been shown to play a role in colorectal, renal, breast, and ovarian cancer, and malignant osteoblasts, and may be associated with more advanced disease. ${ }^{32-39}$ The notion of reduced Rl $\alpha$ activity had not been investigated prior to the discovery of it being the protein that was defective in CNC; CNC represents the first identified human disease associated with a mutation of the PKA heterotetramer. The majority of mutations in the PRKARIA gene result in premature stop codons, with the most frequent mutations found in exons 2,4 , and $6{ }^{40}$ Predicted mutant protein products are not found in affected cells secondary to nonsense mRNA mediated decay (NMD) of the mutant sequence. $^{31}$ Biochemically, loss of $\mathrm{Rl} \alpha$ leads to increased cAMP stimulated total kinase activity, ${ }^{31}$ thought to be secondary to up regulation of other components of the PKA tetramer, $^{41}$ including both type I (PRKARIB) and type II (PRKAR2A or PRKAR2B) subunits, in a tissue dependent manner, ${ }^{20}$ but how this leads to increased tumourigenesis is currently unknown.

Initial data supported the role of PRKARIA as a "classic" tumour suppressor gene with tumours from CNC patients exhibiting germline mutations and subsequent $\mathrm{LOH}$ at the PRKARIA locus; however, it now appears that haploinsufficiency of PRKARIA may be sufficient for phenotypic expression of increased PKA activity ${ }^{42}$ and the development of certain tumours, such as eyelid myxomas. ${ }^{43}$ This concept is exemplified in animal models of CNC: whereas mice homozygous for $\mathrm{Rl} \alpha$ deletions die early in utero, ${ }^{44}$ transgenic mice with heterogeneous expression of an antisense transgene for exon 2 of PRKARIA exhibit many of the phenotypic characteristics of CNC patients, including thyroid follicular hyperplasia and non-dexamethasone suppressible hypercortisolism. ${ }^{45}{ }^{46}$ Not all of these lesions exhibited consistent losses of the normal Rl $\alpha$ allele. ${ }^{46} 49$

Examination of the mechanisms associated with loss of Rl $\alpha$, increased PKA activity, and tumourigenesis are currently underway. PKA is a ubiquitous serine-threonine kinase intimately involved in the regulation of cell growth, including a potential role in chromosome stability. ${ }^{21}$ The cross talk between signal transduction pathways and the tissue specific effects of altered PKA function are inherently quite complex, reflected by at times conflicting data. For example, alterations of $17 \mathrm{q}$ and/or the PRKARIA locus have been found in both sporadic adrenal and thyroid cancers, yet allelic loss of $17 \mathrm{q}$ in cardiac and skin myxomas from CNC patients, with known germline PRKARIA mutations, have not been found. ${ }^{21}{ }^{43}$ Interestingly, CNC myxomas appear to have a more aggressive nature when compared to sporadic, nonCNC-associated myxomas, as discussed previously.

The physiological impact of PRKARIA inactivating mutations has been most thoroughly studied in PPNAD, a rare form of ACTH independent CS, which is present in approximately one third of CNC patients. PPNAD often presents in an indolent fashion and may be difficult to diagnose due to an intermittent or cyclical nature of the associated hypercortisolism..$^{22}$ Diagnosis is established using the 6 day Liddle test as patients with PPNAD show a paradoxical rise in the $24 \mathrm{~h}$ urinary free cortisol and/or 17hydroxysteroids of more than $50 \%$ on the second day of high dose dexamethasone administration. ${ }^{24}$ While this response appears to be pathognomonic for PPNAD, it does not appear to be dependent on the presence of PRKARIA mutations as comparative in vitro studies between PPNAD cell lines with and without Rl $\alpha$ deficiency showed increased cortisol secretion in response to dexamethasone associated with increased expression of the glucocorticoid receptor. ${ }^{47}$ The underlying mechanism for this response is not known.

Additional studies aimed at elucidating the inter-relationship between PRKARIA status, altered PKA activity, and cellular metabolism are being aggressively pursued. Microarray analysis of $\mathrm{Rl} \alpha$ antisense targeted tumour cells 


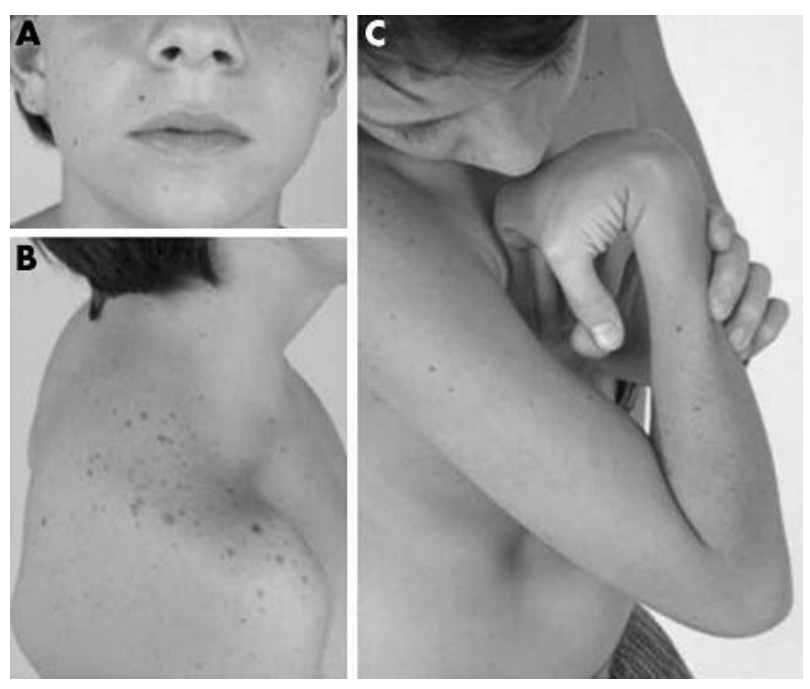

Figure 2 Features of Noonan/LEOPARD syndromes. (A) Pigmented lesions on the face can mimic those of patients with Carney complex, but they tend not to be present on the lips or periorally; they occur mostly as single darkly pigmented spots and look less like freckles. (B) Lentigines on the shoulders and the back can be extensive; winged scapulae is also an evident deformity in this patient. (C) Skeletal deformities, scoliosis and hyperextensibility, like that shown in this image, are not unusual in patients with this condition. (These photographs are reproduced with consent.)

has recently been shown to change expression of more than 240 genes suggesting that altered regulation of a significant number of downstream targets is likely to contribute to the CNC phenotype. ${ }^{48}$ Investigation of one of the signalling pathways, the mitogen activated protein kinase (MAPK) ERK $1 / 2$ pathway, typically inhibited by PKA in many cells, has recently been reported. In this report, the lymphocytes from CNC patients with known PRKARIA mutations showed altered PKA activity and increased ERK 1/2 phosphorylation. ${ }^{42}$ Cell metabolism and cell proliferation studies suggested that altered PKA activity is associated with reversal of PKA mediated inhibition of the MAPK pathway resulting in increased cell proliferation. ${ }^{42}$

\section{LEOPARD SYNDROME}

LEOPARD is also often referred to as multiple lentigines syndrome (MLS). The acronym, which also describes the pattern of pigmentation (fig 2), was suggested first by Gorlin et al in $1969^{50}$ and reflects the components of this cardiocutaneous disorder: lentigines, electrocardiographic conduction defects, ocular hypertelorism, pulmonary stenosis, abnormal genitalia, retardation of growth, and sensorineural deafness. ${ }^{5152}$ The diagnosis is established if multiple lentigines are present in association with at least two other features; if lentigines are absent, a first degree relative affected with LEOPARD syndrome and three of the other six features are needed for diagnosis. ${ }^{52}$

As in CNC patients, the lentigines usually develop in childhood and are often the first clinical manifestation to appear $^{52}$; they are located primarily on the face and upper trunk, less commonly involving the oral mucosa, extremities, genitalia, or conjuctiva of the eye. ${ }^{53}$ The appearance and distribution of the lentigines are very similar to CNC, as is the histological appearance, including melanocytic hyperplasia and elongation of the rete ridges. One important difference is the absence of pigmented spots along the vermilion border of the lips, a finding that is characteristic in CNC and PJS patients. Also, skeletal abnormalities, onychodystrophy, and hyperelastic skin, which are often found in LEOPARD syndrome patients, are not common in other lentiginoses. ${ }^{52} 53$ The craniofacial features of LEOPARD syndrome are generally coarse and include low set and posteriorly rotated ears, hypertelorism with or without ptosis, webbed neck, and mandibular prognathism. ${ }^{52}$ These features, combined with an increased incidence of pulmonic stenosis, show significant phenotypic overlap with Noonan syndrome (MIM 163950); furthermore, hyperelasticity and other features partially overlap with Ehlers-Danlos syndrome subtypes and the arterial dissections with lentiginosis (ADL) syndrome (see below)..$^{52}$

Morbidity and mortality associated with LEOPARD syndrome are dependent on the extent of cardiac disease. Multiple congenital heart defects have been reported to include not only pulmonic stenosis (present in $40 \%$ of patients) but also subaortic and subpulmonic stenosis, and hypertrophic obstructive cardiomyopathy..$^{53}$ In addition, conduction abnormalities are common and whether they are a primary defect, or secondary to structural abnormalities, may result in sudden cardiac death. ${ }^{54}$ More recently, a predisposition to widespread, recurrent polyaneurysms has been reported in a patient with genetically confirmed LEOPARD syndrome. ${ }^{55}$ Although unproven, it is interesting to speculate whether patients previously diagnosed with the ADL disorder (MIM 600459) may be more appropriately reclassified as having a variant of LEOPARD syndrome; to our knowledge, these patients have not had genetic testing. ${ }^{56}$

\section{Molecular mechanism}

The clinical similarities between LEOPARD and Noonan syndrome (NS), and the series of patients with both lentigines and NS-like features (NSL), raised the question whether these syndromes could be allelic disorders with varied clinical expression. Some of the patients with NSL had in fact Watson syndrome, a condition that is allelic to neurofibromatosis type I. Still, LEOPARD, NS, and NSL share similar craniofacial features, an increased incidence of sensorineural deafness and cryptorchidism, and associated pulmonic stenosis. In total, up to $10 \%$ of NS patients have lentigines. ${ }^{57}$ In 1996, mutations in the PTPNII gene (12q24.1), encoding the non-receptor tyrosine protein tyrosine phosphatase Shp-2 (Src homology 2 domain containing protein tyrosine phosphatase-2), were found to be the cause of NS in 50\% of patients. ${ }^{58}$ In 2002, independent research groups published reports linking PTPNIl mutations to LEOPARD syndrome. $^{5960}$

Shp-2 is an important intermediate in several signalling pathways involved in modulating cellular proliferation, differentiation, and migration. Vertebrates have two Shp proteins, Shp-l and Shp-2, both having two N-terminal domains, N-SH2 and C-SH2, a catalytic protein-tyrosine phosphatase (PTP) domain, and a C-terminal tail. ${ }^{61} \mathrm{Shp} 2$ is a key regulatory protein in the receptor tyrosine kinase (RTK) signalling pathways whose primary role is to down regulate GTPase activating proteins (GAP) resulting in activation of Ras. ${ }^{61}$ In the basal state, the N-SH2 domain of Shp-2 exhibits an inhibitory role over the phosphatase activity by allosterically blocking the binding domain of PTP. ${ }^{61}$ To date, the PTPN11 mutations that have been described in both NS and LEOPARD are believed to be gain of function mutations leading to dysregulated phosphatase activity with subsequent increased inhibition of GTPase which in turn leads to increased Ras activity. ${ }^{61}{ }^{62}$ In keeping with this, in vitro studies of haematopoietic cell lines harbouring PTPNII mutations show increased proliferation rates and reduced growth factor requirements. ${ }^{62}$

How these abnormalities result in human disease and what intermediary molecules and additional downstream targets of Shps are affected by mutations of the PTPNII gene are as 


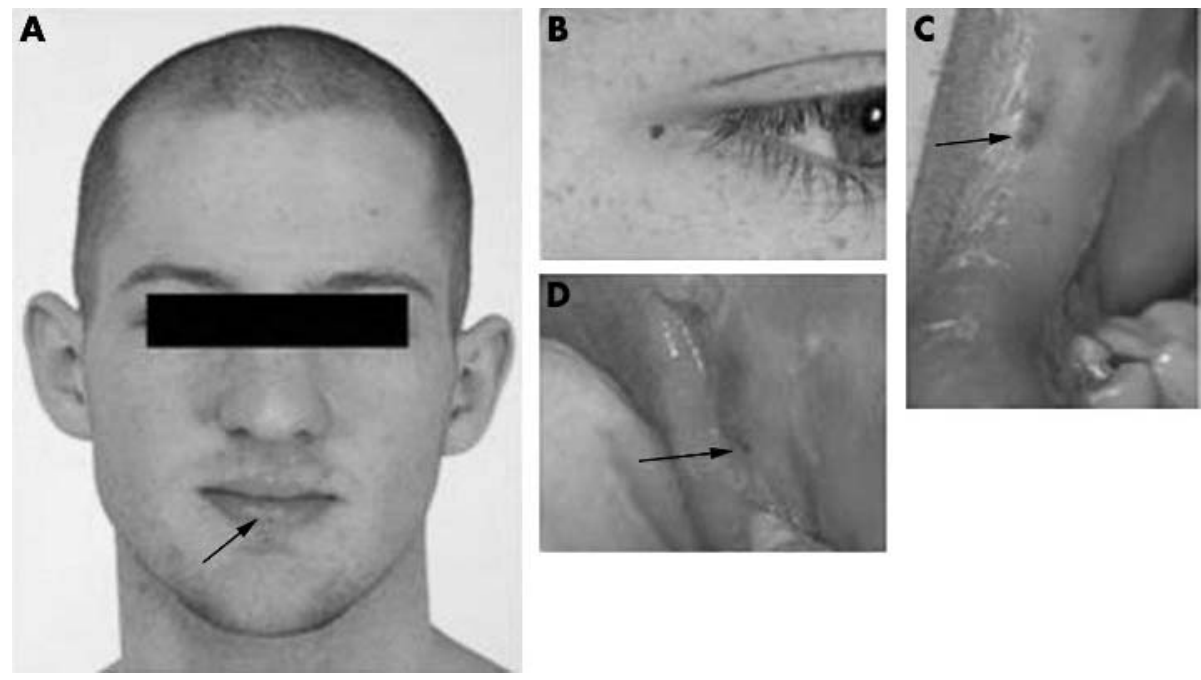

Figure 3 Pigmentation in Peutz-Jeghers syndrome looks similar to that in Carney complex except that single lesions tend to be larger and more pigmented. (A) Lentigines on the vermillion border of the lips and a darkly pigmented lesion on the mucosa (arrow). (B) Freckling around the eyes with multiple lentigines. (C, D). Pigmented lesions in the oral mucosa are frequent in patients with this syndrome, perhaps more frequent than in any other lentiginosis. (These photographs are reproduced with consent.)

yet poorly understood. It is of interest to note, however, that SHP-2 has mitogenic effects on vascular smooth muscle and interacts with several key elements of angiogenesis, including the angiopoietin-1 receptor and the signalling cascade of vascular endothelial growth factor (VEGF)..$^{54}$

Accumulating evidence suggests that certain germline PTPN11 mutations play a key role in certain manifestations of LEOPARD, NS, and/or NSL, such as the malformations of the cardiovascular system and predisposition to certain malignancies. ${ }^{54}$ For example, exon 8 mutations were more commonly associated with pulmonary valve stenosis, and exon 7 and 12 mutations were more frequently associated with hypertrophic cardiomyopathy, whereas those of exon 3 were associated with atrial septal defects. ${ }^{63}$ Certain mutations are also associated with malignancies in both the germline and somatic state: although neoplasms are uncommon in LEOPARD patients, children with NS have an increased incidence of haematological disorders, including juvenile myelomonocytic leukaemia (JMML). ${ }^{62}$ Recent studies indicated that in addition to mutations in the Ras oncogene and inactivating mutations of NFl, in a mutually exclusive manner, $25-30 \%$ of JMML cases harboured somatic PTPNII mutations. ${ }^{62}{ }^{64}$ These mutations are found in similar locations as those found in LEOPARD and NS, but resulted in different amino acid substitutions. ${ }^{61}$ This apparent genotype-phenotype correlation was further supported by the observations made in a transgenic mouse model which expressed a heterozygous NS associated PTPN11 mutation (D61G) developing short stature, craniofacial abnormalities, myeloproliferative disease, and multiple cardiac defects. ${ }^{65}$

\section{PEUTZ-JEGHERS SYNDROME}

PJS is a disorder characterised by mucocutaneous lentigines (lips, buccal mucosa), gastrointestinal (GI) hamartomatous polyps (affecting the small bowel, stomach, and large colon), and an increased risk of developing early onset adenocarcinoma of the GI tract, as well as tumours of the pancreas, breast, thyroid, and reproductive organs. ${ }^{66}{ }^{67}$ There is significant clinical overlap between PJS and CNC to the point that some patients with CNC in the NIH series had been diagnosed with PJS ${ }^{68}$ (the opposite is less frequent since PJS is a widely known condition, whereas CNC was only recently described). As in CNC, patients with PJS may have lentigines of the lips, buccal mucosa, genitals, or the hands and feet (fig 3), which tend to fade in older $\operatorname{age}^{2}$ (an important consideration in the evaluation of the older patient with multiple hamartomatous GI polyps) and a number of other skin lesions (mostly compound but also blue and Spitz nevi), thyroid tumours, and an increased incidence of gonadal tumours. Most males with PJS, as patients with CNC, have upon sonographic examination testicular micro-calcifications which reflect the presence of multiple foci of large cell calcifying Sertoli cell tumours (LCCSCTs). Leydig cell tumours are less frequent, as in CNC. LCCSCTs may express aromatase and lead to precocious puberty and gynaecomastia, ${ }^{68}$ clinical findings that are more common in boys with PJS than in those with CNC. Females with PJS develop a variety of gynaecological neoplasms; their high prevalence and histological subtypes are at variance with those of women with $\mathrm{CNC}^{27}$

It was recently reported that the cumulative life long risk for developing cancer in a patient with PJS exceeds $90 \% .{ }^{66}$ There does not appear to be a risk difference between genders, with the exception of gonadal malignancies and breast cancer, which are far more common in females. ${ }^{69}$ The mean age of diagnosis of a first cancer was $42.9 \pm 10.2$ years in one study.$^{63}$ The most recent study of 240 patients with PJS (188 familial and 52 sporadic cases were included), all with confirmed genetic defects, showed an age dependent risk of developing cancer as follows: $1 \%$ at age $20,3 \%$ at $30,19 \%$ at $40,32 \%$ at $50,63 \%$ at 60 , and $81 \%$ at 70 years. ${ }^{69}$ Overall, 54 malignancies were diagnosed in 47 carriers; GI (oesophageal, stomach, small bowel, colon, rectum, and pancreas) and breast cancers were the most common. Compared to the general population, the risk of developing colorectal and breast cancer in PJS by age 60 was $42 \%$ and $32 \%$ versus $1 \%$ and $5 \%$, respectively. ${ }^{69}$ Thus, breast cancer risks in women with PJS are comparable to those of women with either $B R C A 1$ or BRCA2 mutations. The optimal time to initiate GI and breast cancer surveillance is still somewhat controversial, although most agree that GI screening (by endoscope, colonoscopy, and abdominal CT) and breast examinations with reproductive tract screening (by pelvic ultrasound, cervical cytology, and serum CA125 levels) should start after age 20 and 25 , respectively. ${ }^{69}$ 


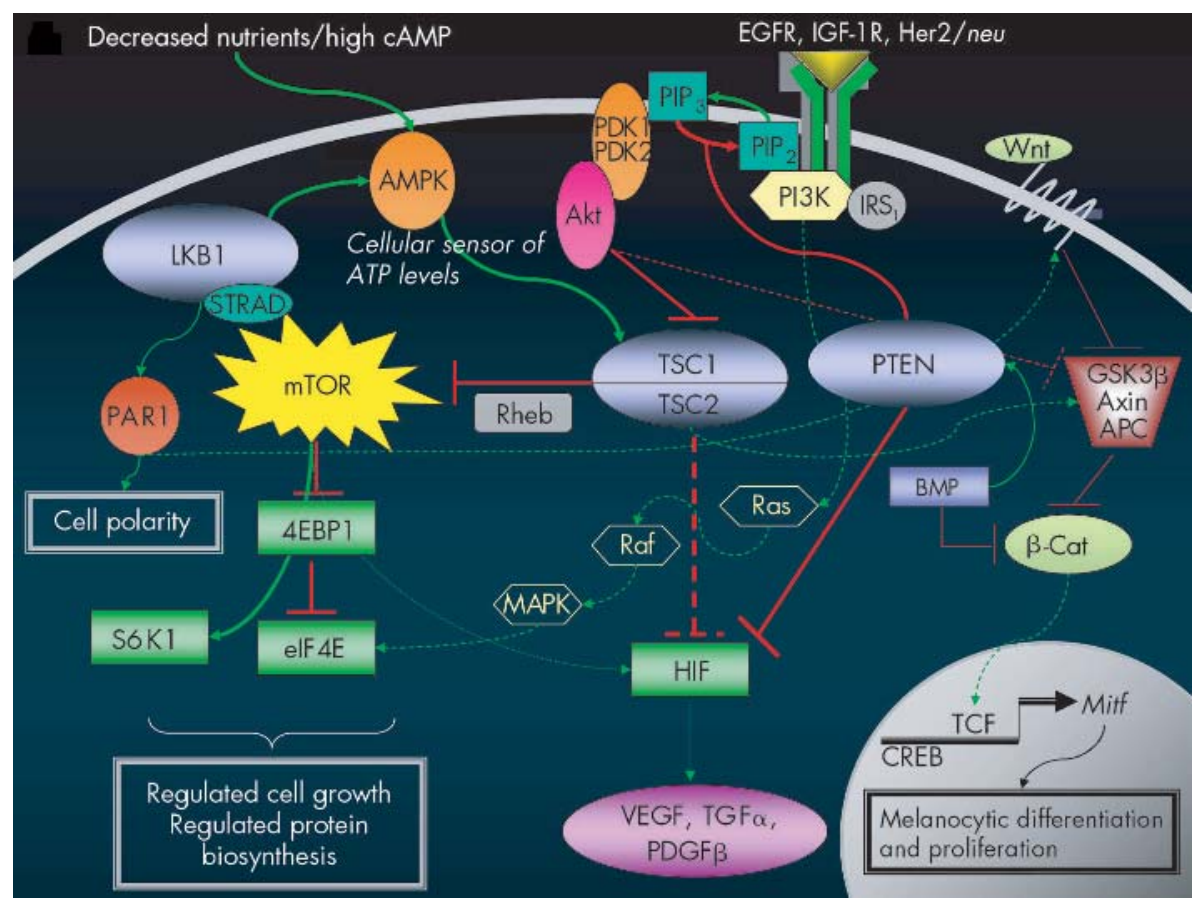

Figure 4 Two independent pathways appear to be critically important in regulating cell growth in response to nutrient supply and mitogenic stimulation: (i) the PKA/PRKARIA-LKB1 tumour suppressor protein pathway, acting via AMPK, and (ii) the PI3K/AKT pathway. Recent evidence suggests that the tumour suppressor gene complex, $\mathrm{TSCl} / \mathrm{TSC} 2$, orchestrates the signal from both pathways to the downstream target, mTOR, which in turn regulates the ribosomal protein S6 and 4EBP-1, a repressor of the translational initiation factor elF4E. In this model, at times of nutrient stress LKB1/AMPK activation of the TSC1/TSC2 complex results in inhibition of mTOR and a decrease in protein synthesis. Under stimulation of mitogenic pathways, PI3K phosphorylates PIP2 to PIP3 resulting in recruitment of AKT to the membrane where it is activated by PDK1. Activated AKT inhibits the TSC1/TSC2 tumour suppressor complex leading to increased mTOR activity. In the later pathway, PTEN antagonises PIP3 action through dephosphorylation, and thus provides an "off" switch for regulating mitogenic pathway induced cellular growth and proliferation. Cross talk of several other pathways appears to play important regulatory roles in the lentiginoses syndromes to include the Ras/MAPK pathway in the regulation of translation, the LKB1 pathway in cellular polarity, the AKT pathway (as well as the TSC1/TSC2 complex) in the regulation of the Wnt/GSK3 $3 / \beta$-Cat pathway, and the BMP pathway in the regulation of PTEN (see text for further discussion). Lastly, both PTEN and mTOR appear to have negative regulatory effects on VEGF through loss of stabilisation of the hypoxia inducible transcription factor 1 (HIF1).

\section{Molecular mechanism}

In 1998, two independent reports identified germline mutations in the gene LKBI/STK11 on 19p13.3, coding for a serine/ threonine kinase, as the cause of PJS in most (but not all) patients. ${ }^{70}{ }^{71}$ To date mutations in $L K B I$ can be found in only $30-80 \%$ of patients; linkage to other loci, including 19q13.4, has also been reported but the causative gene(s) have not been identified. ${ }^{72} 73$ LKBI appears to function as a classic tumour suppressor following Knudson's two hit hypothesis, at least as far as the development of GI neoplasms is concerned. Interestingly, LKBI also appears to play a role in two additional key regulatory pathways, involved in controlling the polarity of epithelial cells and as the master regulator of AMP dependent kinase, the central sensor of cellular ATP levels and key regulator of cellular energy consumption ${ }^{74-77}$; LKBI may also be interacting with PRKARlA, and is phosphorylated by PKA (fig 4).

\section{The lentiginoses and the mTOR pathway}

It has recently been suggested that $L K B I$ defects lead to dysregulation of the downstream target mTOR, the mammalian target of rapamycin, a key regulator of protein translation. ${ }^{78} 79$ mTOR is a highly conserved serine/threonine kinase that mediates cellular growth by sensing information on the cellular energy status and mitogenic signals and then coordinating the activity of the translational machinery of the cell through regulation of the ribosomal protein S6 kinases (S6Ks) and the eukaryotic translational initiation factor 4E (eIF4E) binding proteins (4E-BPs). ${ }^{80}$ Dysregulated activation of mTOR is believed to allow growth of cells to occur at times of reduced nutrient or energy supply and independently of mitogenic stimuli with the "uncoupling" hypothesised to be the underlying mechanism responsible for the formation of hamartomas and neoplasia in PJS and other conditions (fig 5). LKBl plays a fundamental role in regulating cellular energy metabolism by down regulating mTOR dependent protein synthesis during times of nutrient stress. ${ }^{81}$ This regulatory control is mediated through the direct activation of AMP activated protein kinase (AMPK), a primary sensor of cellular response to reduced ATP levels. AMPK is activated by a variety of stimuli, including oxidative and osmotic damage, hypoxia, and hypoglycaemia. ${ }^{81}$ Once activated, AMPK phosphorylates and activates tuberin (encoded by the tumour suppressor TSC2 and mutated in tuberous sclerosis type II), resulting in inhibition of mTOR signalling. ${ }^{82}$ At the basal state, LKBl protects cells from apoptosis by reducing protein synthesis at times of stress. Loss of LKBI function results in dysregulated mTOR mediated protein synthesis ${ }^{74-79}$; in addition, aberrant TSC1/ TSC2 and/or mTOR signalling in these cells results in increased angiogenesis through activation of hypoxia inducible factor 1 (HIF) and VEGF. ${ }^{83}$ Consistent with the above, $L k b l$ deficient mice develop intestinal hamartomatous polyps $^{84}{ }^{85}$ and hepato-cellular carcinoma. ${ }^{86}$ Interestingly, Lkbl deficient cells are resistant to Ras induced transformation, ${ }^{84}$ as would have been expected from a disruptor of mTOR signalling. While these alterations shed light on aberrant cellular metabolism and may explain why cells without normal LKBI function show immortalised growth and decreased apoptosis, they do not fully explain the 


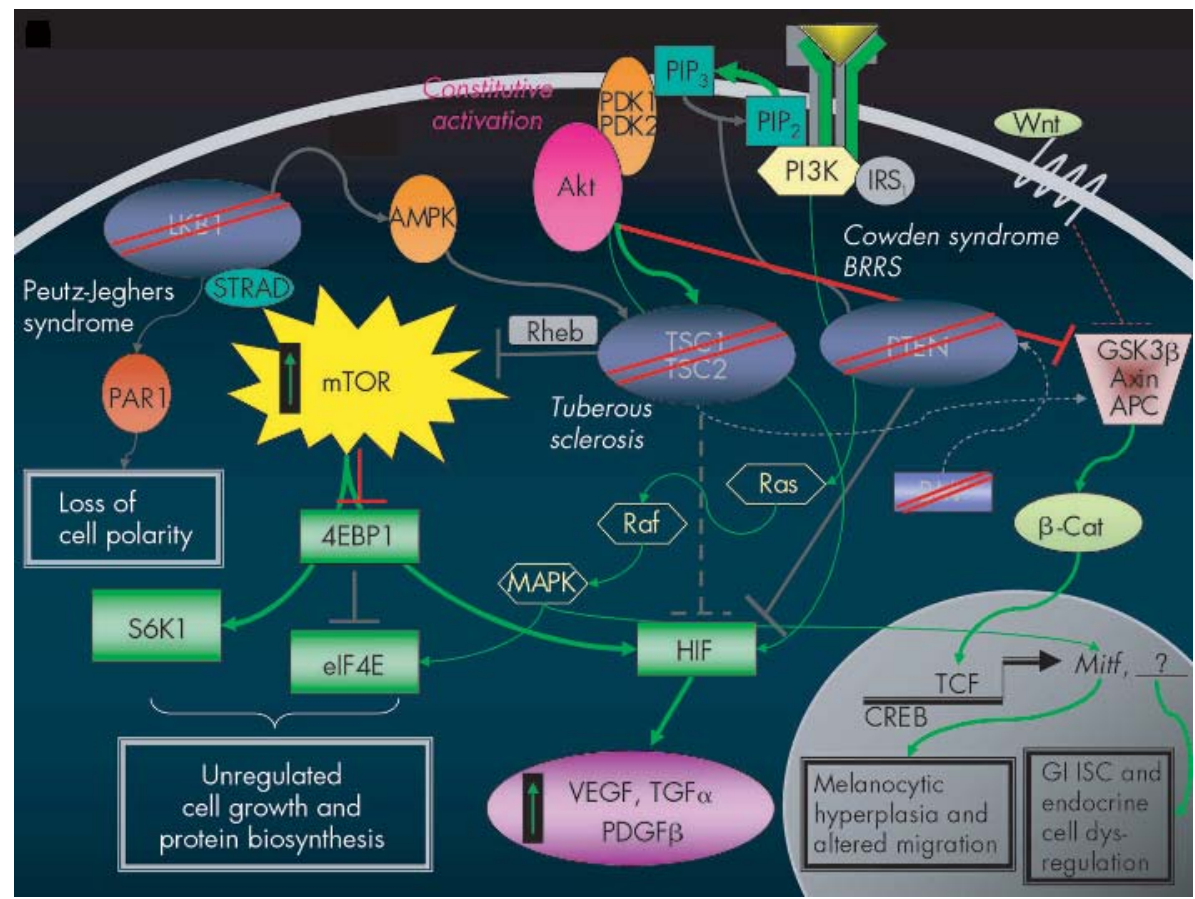

Figure 5 Loss of function of the tumour suppressor proteins LKB1 (or its regulator PKA/PRKAR1A) in Peutz-Jeghers syndrome, and PTEN and BMP in Cowden syndrome/Banayan-Riley-Ruvalcaba (or TSC1/TSC2 in tuberous sclerosis) leads to a proliferative advantage for the affected cells by switching on the protein translational machinery of the cells which advances cellular growth. In addition, LKB1 is required to maintain an organised, polarised epithelium in a cell to cell interaction independent manner; loss of LKB1 leads to loss of cellular polarity and loss of PTEN function to increased levels of PIP3, increased AKT, mTOR, $\beta$-catenin, and HIF activity. Accumulating evidence suggests that dysregulated activity of mTOR and the downstream effectors S6K1, 4EBP1, and HIF, as well as down regulation of the GSK3b complex with increased $\beta$-Cat activity may be the triggering mechanism for hamartoma formation in the aforementioned syndromes.

apparent tumourigenic affect of $L K B 1$ mutations. Further study of the $L K B 1$ pathway and its interaction with other signalling molecules, including the LKBl specific adaptor protein STRAD, and other intermediaries (PAR1, PKA, or any of the 13 or more additional kinases of the AMPK subfamily) will need to be completed to more fully understand how LKBl choreographs cellular organisation and growth. ${ }^{747687}$

\section{Laugier-Hunziker syndrome}

Laugier-Hunziker syndrome (LHS) is a rare, sporadic disorder, originally described in 1970, that is often confused with PJS due to similar appearance and distribution of hyperpigmented cutaneous and mucocutaneous lesions. ${ }^{88} 89$ Family history and screening for mutations may not aid in distinguishing this disorder from PJS as up to $25 \%$ of PJS cases are sporadic, and as previously reviewed, LKBI mutations may be found in only $30-80 \%$ of cases. $^{75}$ Accurate clinical diagnosis is essential as patients with LHS are not at an increased risk of developing GI tumours and they do not need any invasive GI tract surveillance. ${ }^{89}$

\section{Ruvalcaba-Myhre-Smith, Bannayan-Zonnana syndrome, and Cowden disease (CD)}

RMS/BZS and CD along with PJS and juvenile polyposis are a group of inherited disorders that have been previously grouped under the general classification of the familial hamartoma syndromes. With the discovery of mutations in the tumour suppressor gene PTEN (10q22-q23) in up to $80 \%$ of CD patients and up to $60 \%$ of RMS/BZS patients, it has been suggested that these conditions should be all listed under the heading "PTEN hamartoma tumour syndromes" (PHTS). ${ }^{90-100}$ Patients with PTEN mutations have an increased risk of developing multiple hamartomas in various organ systems such as the breast, thyroid, skin, central nervous system, and GI tract. ${ }^{98}$ Some distinguishing features of RMS/
BZS include delayed motor development, and most germane to our discussion, the presence of lentigines, especially on the glans penis, known as the "speckled penis". ${ }^{98}$ The association of macrocephaly, lipomatosis, and speckled penis is also known as the Bannayan-Riley-Ruvalcaba triad. ${ }^{96}$ Hyperpigmentation of the glans penis typically develops during childhood; in $90 \%$ of CD patients, mucocutaneous signs develop by 20 years of age..$^{98-100}$ Diagnostic criteria for PHTS, and a thorough review of this topic, were recently published. ${ }^{101}$ It should be noted that PTEN mutations have also been found in several other conditions, including Proteus syndrome (PS; MIM 176920) and Proteus-like disorders, ${ }^{102-104}$ Lhermitte-Duclos disease (LDD), and other rare syndromes. ${ }^{105} 106$

\section{Molecular mechanism}

PTEN (phosphatase and tensin homolog deleted on chromosome 10) is a dual specific phosphatase that plays a key role in cell growth, differentiation, apoptosis, membrane trafficking, cellular interactions, and cellular motility. ${ }^{99} 107108$ The mechanics of how PTEN regulates such diverse and key regulatory pathways has been the focus of intense research as early on it was recognised that inactivation of PTEN/MMAC (mutated in multiple advanced cancers) effected a large number of cancers and appeared to correlate with advanced disease in CNS glial tumours (glioblastoma multiforme and anaplastic astrocytoma), advanced prostate cancer, and metastatic breast cancer. ${ }^{107}{ }^{108}$ The early reports of PTEN's inhibitory regulation of the phosphoprotein focal adhesion kinase (FAK) and its effects on decreasing cell spreading and motility have since given way to the ever increasing body of research on the regulator role of PTEN on the phospholipids, and of particular interest, the ability of PTEN to regulate the plasma membrane inositol phospholipids functioning as the "off" switch for the phosphoinositide 3-kinase (PI3K) 
signalling pathway. ${ }^{107-109}$ It has now been suggested that loss of PTEN activity leads to constitutive activation of the cytosolic signalling protein AKT. ${ }^{109}$ One of the key downstream targets of AKT is the tuberin-hamartin complex (TSC1/TSC2), mutations of which are associated with the hamartomatous syndrome tuberous sclerosis. ${ }^{110}$ Early evidence suggests that the tuberin-hamartin complex, through inhibition of mTOR signalling, inhibits the $70 \mathrm{kDa}$ ribosomal S6 kinase ( $56 \mathrm{Kl}$ ) and eukaryotic initiation factor 4E binding protein (4E-BP1), key mediators of the protein translational machinery. ${ }^{110}$ In this model, loss of PTEN function results in the constitutive activation of AKT, down regulation of tuberin/TSC2 and mTOR, and subsequent promotion of cell cycle progression and suppression of apoptosis. Elucidation of this pathway, mediated through mTOR, now provides a link for the previous observation linking the role of mitogenic stimuli in breast, colon, and prostate cancer, as well as in the hamartomatous tumour syndromes PJS, tuberous sclerosis, and $\mathrm{CD} .{ }^{107} \mathrm{~A}$ more thorough review of the role of mTOR and translation in cancer pathogenesis has recently been published. ${ }^{11-114}$ The role of the bone morphogenetic proteins (BMP) in regulating PTEN levels was also recently revealed. ${ }^{115-117}$ Bmprla mutant mice develop intestinal polyps, an effect that is largely due to loss of BMP inhibition of PTEN function and to some extent Wnt signalling cross talk. ${ }^{117} 118$

\section{SUMMARY: LENTIGINES, A CLINICAL SIGN OF MOLECULAR CONVERGENCE?}

Although much remains to be learned, there is compelling evidence to suggest that the apparently different pathways that result in the main lentiginoses are also involved in melanocytic differentiation and migration. Under the direction of several key regulatory signals, including those from the Wnt family of proteins, fibroblast growth factors, and BMPs, neural crest cells differentiate along the dorso-lateral pathway that gives rise to the melanocytes. ${ }^{119-121}$ Interactions with factors such as the microphthalmia associated transcription factor (Mitf), mTOR, and possibly BRAF and the dickkopf proteins (DKK) may provide a molecular basis as to why the melanocyte is affected in such a way in these disparate disorders. ${ }^{122}$ Figures 4 and 5 provide a summary of what we have learnt in the last 10 years about the lentiginoses, but we are still a long way away from knowing what we should know to treat our patients!

\section{Authors' affiliations \\ A J Baver, C A Stratakis, Section on Endocrinology and Genetics} (SEGEN), Developmental Endocrinology Branch (DEB), National Institute of Child Health and Human Development (NICHD), National Institutes of Health, Bethesda, MD 20892-1103, USA

A J Baver, Walter Reed Army Medical Center, Department of Pediatrics, Washington, DC 20307, USA

Competing interests: none declared

Consent was received for the publication of personal details and photographs

The opinions or assertions contained herein are the private views of the authors and are not to be construed as official or to reflect the opinions of Walter Reed Army Medical Center, the United States Army, or the Department of Defense.

\section{REFERENCES}

1 Rosenzweig JL, Lawrence DA, Vogel DL, Costa J, Gorden P. Adrenocorticotropin-independent hypercortisolemia and testicular tumors in a patient with a pituitary tumor and gigantism. J Clin Endocrinol Metab 1982:55:421-7.

2 Stratakis CA. Genetics of Peutz-Jeghers syndrome, Carney complex and other familial lentiginoses. Horm Res 2000;54:334-43.

3 Marsh DJ, Stratakis CA. Hamartoma and lentiginoses syndromes: clinical and molecular aspects. Front Horm Res 2001;28:167-213.
4 Boerkoel CF, Takashima H, John J, Yan J, Stankiewicz P, Rosenbarker L, Andre JL, Bogdanovic R, Burguet A, Cockfield S, Cordeiro I, Frund S, Illies F, Joseph M, Kaitila I, Lama G, Loirat C, McLeod DR, Milford DV, Petty EM, Rodrigo F, Saraiva JM, Schmidt B, Smith GC, Spranger J, Stein A, Thiele H, Tizard J, Weksberg R, Lupski JR, Stockton DW. Mutant chromatin remodeling protein SMARCAL1 causes Schimke immuno-osseous dysplasia. Nat Genet 2002;30:215-20.

5 de Silva DC, Wheatley DN, Herriot R, Brown T, Stevenson DAJ, Helms P, Dean JCS. Mulvihill-Smith progeria-like syndrome: a further report with delineation of phenotype, immunologic deficits, and novel observation of fibroblast abnormalities. Am J Med Genet 1997;69:56-64.

6 Allanson JE, Upadhyaya M, Watson GH, Partington M, MacKenzie A, Lahey D, MacLeod H, Sarfarazi M, Broadhead W, Harper PS. Watson syndrome: is it a subtype of type 1 neurofibromatosis? J Med Genet 1991:28:752-6.

7 Weinstein LS, Liu J, Sakamoto A, Xie T, Chen M. Minireview: GNAS: normal and abnormal function. Endocrinology 2004;145:5459-64.

8 Chen W, Fan PC, Happle R. Partial unilateral lentiginosis with ipsilateral Lisch nodules and axillary freckling. Dermatology 2004;209:321-4.

9 Tadini G, Restano L, Gonzales-Perez R, Gonzales-Ensenat A, VincenteVilla MA, Cambiaghi S, Marchettini P, Mastrangelo M, Happle R. Phacomatosis pigmentokeratotica: report of new cases and further delineation of the syndrome. Arch Dermatol 1998;134:333-7.

10 Magnaldo T, Sarasin A. Xerodermapigmentosum: from symptoms and genetics to gene-based skin therapy. Cells Tissues Organs 2004;177:189-98

11 Maize JC, Ackerman AB. Pigmented lesions of the skin: clinicopathologic correlations. Philadelphia, PA: Lea \& Febiger, 1987:228-42.

12 Rhodes AR. Benign neoplasias and hyperplasias of melanocytes and dysplastic melanocytic nevi. In: Freedberg IM, Eisen AZ, Wolff K, et al. Dermatology in general medicine. 5th ed. New York: McGraw-Hill, 1999:1018-79.

13 Online Mendelian Inheritance in Man. http://www.ncbi.nlm.nih.gov/ entrez/query. fcgi? db $=$ OMIM

14 Touraine A. Une nouvelle neuro-ectodermose congenitale: la lentiginose centro-faciale et ses dysplasies associees. Ann Derm Syph 1941;8:453-73.

15 Touraine A. L'Heredite en medecine. Paris: Masson, 1955.

$16 \mathbf{O}^{\prime}$ Neil JF, James WD. Inherited patterned lentiginoses in blacks. Arch Dermatol 1989;125:1231-5.

17 Zanardo L, Stolz W, Schmitz G, Kaminski W, Vikkula M, Landthaler M, Vogt T. Progressive hyperpigmentation and generalized lentiginoses without associated systemic symptoms: a rare hereditary pigmentation disorder in South-East Germany. Acta Derm Venereol 2004;84:57-60.

18 Pacheco TR, Oreskovich NM, Bellus GA, Talbert J, Old W, Fain PR. Exclusion of candidate genes and loci for multiple lentigines syndrome. J Invest Derm 2002;119:535-7.

19 Bain F. "Carney complex". Mayo Clin Proc 1986;61:508.

20 Stergiopoulos SG, Stratakis CA. Human tumors associated with Carney complex and germline PRKARIA mutations: a protein kinase $A$ disease FEBS Lett 2003;546:59-64.

21 Bossis I, Voutetakis A, Bei T, Sandrini F, Griffin KJ, Stratakis CA. Protein kinase $A$ and its role in human neoplasia: the Carney complex paradigm. Endocr Relat Cancer 2004; 11:265-80.

22 Sandrini F, Stratakis CA. Clinical and molecular genetics of Carney complex. Mol Genet Metab 2003;78:83-92.

23 Chrousos GP, Stratakis CA. Carney complex and the familial lentiginoses syndromes: link to inherited neoplasias and developmental disorders, and genetic loci. J Int Med 1998;243:573-9.

24 Stratakis CA, Kirschner LS, Carney JA. Clinical and molecular features of the Carney complex: diagnostic criteria and recommendations for patient evaluation. J Clin Endocrinol Metab 2001;86:4041-6.

25 Carney JA, Stratakis CA. Epitheliod blue nevus and psammomatous melanotic schwannoma: the unusual pigmented skin tumors of the Carney complex. Sem Diag Pathol 1998;15:216-24.

26 Stratakis CA, Papageorgiou T, Premkumar A, Pack S, Kirschner LS, Taymans S, Zhuang Z, Oelkers WH, Carney JA. Ovarian lesions in Carney complex: clinical genetics and possible predisposition to malignancy. J Clin Endocrinol Metab 2000;85:4359-66.

27 Stratakis CA, Papageorgiou T. Ovarian tumors associated with multiple endocrine neoplasias and related syndromes (Carney complex, PeutzJeghers syndrome, von Hippel-Lindau disease, Cowden's disease). Int J Gynecol Cancer 2002; 12:337-47.

28 Stratakis CA, Courcoutsakis NA, Abati A, Filie A, Doppman JL, Carney JA, Shawker T. Thyroid gland abnormalities in patients with the syndrome of spotty skin pigmentation, myxomas, endocrine overactivity and schwannomas (Carney complex). J Clin Endocrinol Metab 1997; 82:2037-43

29 Sandrini F, Matyakhina L, Sarlis NJ, Kirschner LS, Farmakidis C, Gimm O, Stratakis CA. Regulatory subunit type 1- $\alpha$ of protein kinase A (PRKAR1A): a tumor suppressor gene for sporadic thyroid cancer. Genes Chromosomes Cancer 2002;35:182-92.

30 Stratakis CA, Kirschner LS, Carney JA. Carney complex, a familial multiple neoplasia and lentiginoses syndrome. Analysis of 11 kindreds and linkage to the short arm of chromosome 2. J Clin Invest 1996;97:699-705.

31 Kirschner LS, Carney JA, Pack SD, Taymans SE, Giatzakis C, Cho YS, ChoChung YS, Stratakis CA. Mutations of the gene encoding the protein kinase A type $\mathrm{I}-\alpha$ regulatory subunit in patients with the Carney complex. Nat Genet 2000;26:89-92

32 Livesey SA, Kemp BE, Re CA, Partridge NC, Martin TJ. Selective hormonal activation of cyclic AMP-dependent protein kinase isoenzymes in normal and malignant osteoblasts. J Biol Chem 1982;257:14983-7. 
33 Fossberg TM, Doskeland SO, Ueland PM. Protein kinases in human renal cell carcinoma and renal cortex. A comparison of isozyme distribution and of responsiveness to adenosine 3': 5'-cyclic monophosphate, Arch Biochem Biophys 1978;189:272-81.

34 Handschin JC, Eppenberger U. Altered cellular ratio of type I and type II cyclic AMP-dependent protein kinase in human mammary tumors. FEBS Lett 1979;106:301-4.

35 Nakajima F, Imashuku S, Wilimas J, Champion JE, Green AA. Distribution and properties of type I and type II binding proteins in the cyclic adenosine $3^{\prime}: 5^{\prime}$-monophosphate-dependent protein kinase system in Wilms' tumor. Cancer Res 1984;44:5182-7.

36 Watson DM, Hawkins RA, Bundred NJ, Stewart HJ, Miller WR. Tumor cyclic AMP binding proteins and endocrine responsiveness in patients with inoperable breast cancer. Br J Cancer 1987:56:141-2.

37 Piroli G, Weisenberg LS, Grillo C, De Nicola AF. Subcellular distribution of cyclic adenosine $3^{\prime}: 5^{\prime}$-monophosphate-binding protein and estrogen receptors in control pituitaries and estrogen-induced pituitary tumors. J Natl Cancer Inst 1990;82:596-601.

38 Bradbury AW, Carter DC, Miller WR, Cho-Chung YS, Clair T. Protein kinase $A(P K A)$ regulatory subunit expression in colorectal cancer and related mucosa. Br J Cancer 1994;69:738-42.

39 McDaid HM, Cairns MT, Atkinson RJ, McAleer S, Harkin DP, Gilmore P, Johnston PG. Increased expression of the Rlalpha subunit of the cAMPdependent protein kinase $A$ is associated with advanced stage ovarian cancer. Br J Cancer 1999;79:933-9.

40 Bossis I, Stratakis CA. PRKARIA: normal and abnormal functions. Endocrinology 2004;145:5452-8.

41 Casey M, Vaughan CJ, He J, Hatcher CJ, Winter JM, Weremowicz S, Montgomery K, Kucherlapati R, Morton CC, Basson CT. Mutations in the protein kinase A R lalpha regulatory subunit cause familial cardiac myxomas and Carney complex. J Clin Invest 2000;106:31-8.

42 Robinson-White A, Hundley TR, Shiferaw M, Bertherat J, Sandrini F Stratakis CA. Protein kinase A activity in PRKAR1A-mutant cells and regulation of mitogen-activated protein kinases ERK1/2. Hum Mol Genet 2003; 12:1475-84.

43 Tsilou ET, Chan CC, Sandrini F, Rubin BI, de Shen F, Carney JA, KaiserKupfer M, Stratakis CA. Eyelid myxoma in Carney complex without PRKARIA allelic loss. Am J Med Genet 2004;130A:395-7

44 Amieux PS, Cummings DE, Motamed K, Brandon EP, Wailes LA, Le K, Idzerda RL, McKnight GS. Compensatory regulation of Rlalpha protein levels in protein kinase A mutant mice. J Biol Chem 1997;272:3993-8.

45 Griffin KJ, Kirschner LS, Matyakhina L, Stergiopoulos S, Robinson-White A Lenherr S, Weinberg FD, Claflin E, Meoli E, Cho-Chung YS, Stratakis CA. Down-regulation of regulatory subunit type $1 \mathrm{~A}$ of protein kinase $\mathrm{A}$ leads to endocrine and other tumors. Cancer Res 2004;64:881 1-5.

46 Griffin KJ, Kirschner LS, Matyakhina L, Stergiopoulos S, Robinson-White A, Lenherr S, Weinberg F, Claflin E, Batista D, Bourdeau I, Voutetakis A, Sandrini F, Meoli E, Bauer A, Cho-Chung YS, Bornstein SR, Carney JA, Stratakis CA. A transgenic mouse bearing an antisense construct of regulatory subunit type $1 A$ of protein kinase $A$ develops endocrine and other tumors: comparison to Carney complex and other PRKAR IA-induced lesions. J Med Genet 2004:41:923-31.

47 Bourdeau I, Lacroix A, Schurch W, Caron P, Antakly T, Stratakis CA Primary pigmented nodular adrenocortical disease: paradoxical responses of cortisol secretion to dexamethasone occur in vitro and are associated with increased expression of the glucocorticoid receptor. J Clin Endocrinol Metab 2003:88:3931-7.

48 Cho YS, Kim MK, Cheadle C, Neary C, Becker KG, Cho-Chung YS Antisense DNAs as multisite genomic modulators identified by DNA microarray. Proc Natl Acad Sci U S A, 2001;98:9819-23.

49 Veugelers M, Wilkes D, Burton K, McDermott DA, Song Y, Goldstein MM, La Perle K, Vaughan CJ, O'Hagan A, Bennett KR, Meyer BJ, Legius E, Karttunen M, Norio R, Kaariainen H, Lavyne M, Neau JP, Richter G, Kirali K, Farnsworth A, Stapleton K, Morelli P, Takanashi Y, Bamforth JS, Eitelberger F, Noszian I, Manfroi W, Powers J, Mochizuki Y, Imai T, Ko GT, Driscoll DA Goldmuntz E, Edelberg JM, Collins A, Eccles D, Irvine AD, McKnight GS, Basson CT. Comparative PRKAR1A genotype-phenotype analyses in humans with Carney complex and prkarla haploinsufficient mice. Proc Natl Acad Sci U S A 2004; 101:14222-7.

50 Gorlin RJ, Anderson RC, Blaw M. Multiple lentigines syndrome. Am J Dis Child 1969;1 17:652-62.

51 Voron DA, Hatfield HH, Kalkhoff RK. Multiple lentigines syndrome: case report and review of the literature. Am J Med 1976;60:447-56.

52 Chong WS, Klanwarin W, Giam YC. Generalized lentiginoses in two children lacking systemic associations: case report and review of the literature. Pediatr Dermatol 2004;21:139-45.

53 Abdelmalek NF, Gerber TL, Menter A. Cardiocutaneous syndromes and associations. J Am Acad Dermatol 2002;46:161-83.

54 Woywodt A, Welzel J, Haase H, Duerholz A, Wiegand U, Potratz J, Sheikhzadeh A. Cardiomyopathic lentiginosis/LEOPARD Syndrome presenting as sudden cardiac arrest. Chest 1998;113:1415-17.

55 Yagubyan M, Panneton J, Lindor NM, Conti E, Sarkozy A, Pizzuti A. LEOPARD syndrome: a new polyaneurysm association and an update on the molecular genetics of the disease. J Vasc Surg 2004;39:897-900.

56 Schievink WI, Michels WV, Mokri B, Piepgras DG, Perry HO. A familial syndrome of arterial dissections with lentiginosis. N Engl J Med 1995:332:576-9.

57 Allanson JE. Noonan syndrome. J Med Genet 1987;24:9-13.

58 Tartaglia M, Mehler EL, Goldberg R, Zampino G, Brunner HG, Kremer H, Van der Burgt I, Crosby AH, Ion A, Kalidas JS, Patton MA, Kucherlapati RS
Gelb BD. Mutations in PTPN1 1, encoding the protein tyrosine phosphatase SHP-2, cause Noonan syndrome. Nat Genet 1996;29:465-8.

59 Digilio MC, Conti E, Sarkozy A, Mingarelli R, Dottorini T, Marino B, Pizzuti A, Dallapiccola B. Grouping of multiple-lentigines/LEOPARD and Noonan syndrome on the PTPN1 1 gene. Am J Hum Genet 2002;71:189-94.

60 Legius E, Schrander-Stumpel C, Schollen E, Pulles-Heintzberger C, Gewillig M, Fryns JP. PTPN1 1 mutations in LEOPARD syndrome. J Med Genet 2002;39:571-4.

61 Neel BG, Gu H, Pao L. The 'Shp'ing news: SH2 domain-containing tyrosine phosphatases in cell signaling. Trends Biochem Sci 2003;28:284-93.

62 Loh ML, Vattikuti S, Schubbert S, Reynolds MG, Carlson E, Lieuw KH, Cheng JW, Lee CM, Stokoe D, Bonifas JM, Curtiss NP, Gotlib J, Meshinchi S, LeBeau MM, Emanuel PD, Shannon KM. Mutations in PTPN1 1 implicate the SHP-2 phosphatase in leukemogenesis. Blood 2004; 103:2325-31.

63 Sarkozy A, Conti E, Seripa D, Digilio MC, Grifone N, Tandoi C, Fazio VM, Di Ciommo V, Marino B, Pizzuti A, Dallapiccola B. Correlation between PTPN 11 gene mutations and congenital heart defects in Noonan and LEOPARD syndromes. J Med Genet 2003;40:704-8.

64 Tartaglia M, Niemeyer CM, Fragale A, Song X, Buechner J, Jung A, Hahlen K, Hasle H, Licht JD, Gelb BD. Somatic mutations in PTPN 11 in juvenile myelomonocytic leukemia, myelodysplastic syndromes and acute myeloid leukemia. Nat Genet 2003;34:148-50.

65 Araki T, Mohi MG, Ismat FA, Bronson RT, Williams IR, Kutok JL, Yang W, Pao LI, Gilliland DG, Epstein JA, Neel BG. Mouse model of Noonan syndrome reveals cell type- and gene dosage-dependent effects of Ptpn 11 mutation. Nat Med 2004; 10:849-57.

66 Amos Cl, Keitheri-Cheteri MB, Sabripour M, Wei C, McGarrity TJ, Seldin MF, Nations L, Lynch PM, Fidder HH, Friedman E, Frazier ML. Genotypephenotype correlations in Peutz-Jeghers syndrome. J Med Genet 2004;41:327-33.

67 Giardiello FM, Brensinger JD, Tersmette AC, Goodman SN, Petersen GM, Booker SV, Cruz-Correa M, Offerhaus JA. Very high risk of cancer in familial Peutz-Jeghers syndrome. Gasteroenterology 2000;119:1447-53.

68 Stratakis CA, Kirschner LS, Taymans SE, Tomlinson IP, Marsh DJ, Torpy DJ, Giatzakis C, Eccles DM, Theaker J, Houlston RS, Blouin JL, Antonarakis SE, Basson CT, Eng C, Carney JA. Carney complex, Peutz-Jeghers syndrome, Cowden disease, and Bannayan-Zonana syndrome share cutaneous and endocrine manifestations, but not genetic loci. J Clin Endocrinol Metab 1998;83:2972-6.

69 Lim W, Olschwang S, Keller JJ, Westerman AM, Menko FH, Boardman LA, Scott RJ, Trimbath J, Giardiello FM, Gruber SB, Gille JJ, Offerhaus GJ, de Rooii FW, Wilson JH, Spigelman AD, Phillips RK, Houlston RS. Relative frequency and morphology of cancers in STK 11 mutation carriers. Gastroenterology 2004; 126:1788-94.

70 Hemminki A, Markie D, Tomlinson I, Avizienyte E, Roth S, Loukola A, Bignell G, Warren W, Aminoff M, Hoglund P, Jarvinen H, Kristo P, Pelin K, Ridanpaa M, Salovaara R, Toro T, Bodmer W, Olschwang S, Olsen AS Stratton MR, de la Chapelle A, Aaltonen LA. A serine/threonine kinase gene defective in Peutz-Jeghers syndrome. Nature 1998;391:184-7

71 Jenne DE, Reimann H, Nezu J, Friedel W, Loff S, Jeschke R, Muller O, Back W, Zimmer M. Peutz-Jeghers syndrome is caused by mutations in a novel serine threonine kinase. Nat Genet 1998;18:38-43.

72 Hearle N, Lucassen A, Wang R, Lim W, Ross F, Wheeler R, Moore I, Shipley J, Houlston R. Mapping of a translocation breakpoint in a PeutzJeghers hamartoma to the putative PJS locus at 19q13.4 and mutation analysis of candidate genes in polyp and STK11-negative PJS cases. Genes Chromosomes Cancer 2004;41:163-9.

73 Boardman LA, Couch FJ, Burgart U, Schwartz D, Berry R, McDonnell SK, Schaid DJ, Hartmann LC, Schroeder JJ, Stratakis CA, Thibodeau SN. Genetic heterogeneity in Peutz-Jeghers syndrome. Hum Mutat 2000;16:23-30.

74 Spicer J, Ashworth A. LKB1 kinase: master and commander of metabolism and polarity. Curr Biol 2004;25:R383-5.

75 Shaw RJ, Bardeesy N, Manning BD, Lopez L, Kosmatka M, DePinho RA, Cantley LC. The LKB1 tumor suppressor negatively regulates $m T O R$ signaling Cancer Cell 2004;6:91-9.

76 Nelson WJ. Cell biology: a cellular choreographer. Nature 2004;428:28-9.

77 Baas AF, Kuipers J, van der Wel NN, Batlle E, Koerten HK, Peters PJ, Clevers HC. Complete polarization of single intestinal epithelial cells upon activation of LKB1 by STRAD. Cell 2004;116:457-66.

78 Shaw RJ, Bardeesy N, Manning BD, Lopez L, Kosmatka M, DePinho RA, Cantley LC. The LKB 1 tumor suppressor negatively regulates $\mathrm{mTOR}$ signaling Cancer Cell 2004;6:91-9.

79 Manning BD, Cantley LC. United at last: the tuberous sclerosis complex gene products connect the phosphoinositide 3-kinase/Akt pathway to mammalian target of rapamycin (mTOR) signaling. Biochem Soc Trans 2003;31 (pt 3):573-7.

80 Fingar DC, Blenis J. Target of rapamycin (TOR): an integrator of nutrient and growth factor signals and coordinator of cell growth and cell cycle progression. Oncogene 2004;23:3151-71.

81 Shaw RJ, Kosmatka M, Bardeesy N, Hurley RL, Witters LA, DePinho RA Cantley LC. The tumor suppressor LKB1 kinase directly activates AMPactivated kinase and regulates apoptosis in response to energy stress. Proc Natl Acad Sci U S A 2004:101:3329-35.

82 Inoki K, Zhu T, Guan LK. TSC2 mediates cellular energy response to control cell growth and survival. Cell 2003;115:577-90.

83 Brugarolas J, Kaelin WG. Dysregulation of HIF and VEGF is a unifying feature of the familial hamartoma syndromes. Cancer Cell 2004;6:7-10.

84 Bardeesy N, Sinha M, Hezel AF, Signoretti S, Hathaway NA, Sharpless NE, Loda M, Carrasco DR, DePinho RA. Loss of the Lkbl tumour suppressor provokes intestinal polyposis but resistance to transformation. Nature 2002;419:162-7. 
85 Miyoshi H, Nakau M, Ishikawa TO, Seldin MF, Oshima M, Taketo MM. Gastrointestinal hamartomatous polyposis in $\mathrm{Lkbl}$ heterozygous knockout mice. Cancer Res 2002;62:2261-6.

86 Nakau M, Miyoshi H, Seldin MF, Imamura M, Oshima M, Taketo MM. Hepatocellular carcinoma caused by loss of heterozygosity in $\mathrm{Lkbl}$ gene knockout mice. Cancer Res 2002;62:4549-53.

87 Lizcano JM, Goransson O, Toth R, Deak M, Morrice NA, Boudeau J, Hawley SA, Udd L, Makela TP, Hardie DB, Alessi DR. LKB1 is a master kinase that activates 13 kinases of the AMPK subfamily, including MARK/PAR1. EMBO J 2004;23:833-43.

88 Laugier P, Hunziker N. Essential lenticular melanic pigmentation of the lip and cheek mucosa (in French). Arch Belg Dermatol Syphiligr 1970;26:391-9

89 Lampe AK, Hampton PJ, Woodford-Richens K, Tamlinson I, Lawrence CM Douglas FS. Laugier-Hunziker syndrome: an important differential diagnosis for Peutz-Jeghers syndrome. J Med Genet 2003;40:e77.

90 Nelen MR, Padberg GW, Peeters EA, Lin AY, van den Helm B, Frants RR, Coulon V, Goldstein AM, van Reen MM, Easton DF, Eeles RA, Hodgsen S, Mulvihill JJ, Murday VA, Tucker MA, Mariman EC, Starink TM, Ponder BA Ropers $\mathrm{HH}$, Kremer $\mathrm{H}$, Longy $\mathrm{M}$, Eng $\mathrm{C}$. Localization of the gene for Cowden disease to chromosome 10q22-23. Nat Genet 1996;13:114-16.

91 Nelen MR, van Staveren WC, Peeters EA, Hassel MB, Gorlin RJ, Hamm H Lindboe CF, Fryns JP, Sijmons RH, Woods DG, Mariman EC, Padberg GW Kremer $\mathrm{H}$. Germline mutations in the PTEN/MMACl gene in patients with Cowden disease. Hum Mol Genet 1997;6:1383-7.

92 Li J, Yen C, Liaw D, Podsypanina K, Bose S, Wang S, Puc J, Miliaresis C, Rodgers L, McCombie R, Bigner SH, Giovanella BC, Ittman M, Tycko B, Hibshoosh $\mathrm{H}$, Wigler $\mathrm{MH}$, Parsons R. PTEN, a putative protein tyrosine phosphatase gene mutated in human brain, breast and prostate cancer. Science 1997;275:1943-7.

93 Li D-M, Sun H. TEP1, encoded by a candidate tumor suppressor locus, is a novel protein tyrosine phosphatase regulated by transforming growth factor B. Cancer Res 1997:57:2124-9.

94 Steck PA, Pershouse MA, Jasser SA, Yung WK, Lin H, Ligon AH, Langford LA, Baumgard ML, Hattier T, Davis T, Frye C, Hu R, Swedlund B, Teng DH, Tavtigian SV. Identification of a candidate tumour suppressor gene, $\mathrm{MMACl}$, at chromosome $10 \mathrm{q} 23.3$ that is mutated in multiple advanced cancers. Nat Genet 1997:15:356-62.

95 Liaw D, Marsh DJ, Li J, Dahia PL, Wang SI, Zheng Z, Bose S, Call KM Tsou HC, Peacocke M, Eng C, Parsons R. Germline mutations of the PTEN gene in Cowden disease, an inherited breast and thyroid cancer syndrome. Nat Genet 1997;16:64-7.

96 Gorlin RJ, Cohen MM Jr, Condon LM, Burke BA. Bannayan-Riley-Ruvalcaba syndrome. Am J Med Genet 1992;44:307-14.

97 Marsh DJ, Coulon V, Lunetta KL, Rocca-Serra P, Dahia PL, Zheng Z, Liaw D, Caron S, Duboue B, Lin AY, Richardson AL, Bonnetblanc JM, Bressieux JM, Cabarrot-Moreau A, Chompret A, Demange L, Eeles RA, Yahanda AM, Fearon ER, Fricker JP, Gorlin RJ, Hodgson SV, Huson S, Lacombe D, Eng C. Mutation spectrum and genotype-phenotype analyses in Cowden disease and Bannayan-Zonana syndrome, two hamartoma syndromes with germline PTEN mutation. Hum Mol Genet 1998;7:507-15.

98 Marsh DJ, Kum JB, Lunetta KL, Bennett MJ Gorlin RJ Ahmed SF, Bodurtha J, Crowe C, Curtis MA, Dasouki M, Dunn T, Feit H, Geraghty MT, Graham JM, Hodgson SV, Hunter A, Korf BR, Manchester D, Miesfeldt S, Murday VA, Nathanson KL, Parisi M, Pober B, Romano C, Tolmie JL, Trembath R, Winter RM, Zachai EH, Zori RT, Weng LP, Dahia PLM, Eng C. PTEN mutation spectrum and genotype-phenotype correlations in Bannayan-RileyRuvalcaba syndrome suggest a single entity with Cowden syndrome. Hum Mol Genet 1999;8:146-72.

99 Waite KA, Eng C. Protean PTEN: form and function. Am J Hum Genet 2002;70:829-44.

100 Eng C. Constipation, polyps or cancer ? Let PTEN predict your future. Am J Hum Genet 2003;122A:315-22.

101 Eng C. PTEN: one gene, many syndromes. Hum Mutat 2003;22:183-98.
102 Biesecker LG, Happle R, Mulliken JB, Weksberg R, Graham JM Jr, Vilioen DL, Cohen $M M$ Jr. roteus syndrome: diagnostic criteria, differential diagnosis, and patient evaluation. Am J Med Genet 1999;84:389-95.

103 Zhou XP, Marsh DJ, Hampel H, Mulliken JB, Gimm O, Eng C. Germline and germline mosaic PTEN mutations associated with a Proteus-like syndrome of hemihypertrophy, lower limb asymmetry, arteriovenous malformations and lipomatosis. Hum Mol Genet 2000;9:765-8.

104 Zhou X, Hampel H, Thiele H, Gorlin RJ, Hennekam R, Parisi M, Winter RM, Eng C. Association of germline mutation in the PTEN tumour suppressor gene and a subset of Proteus sand Proteus-like syndromes. Lancet $2001 ; 358: 210-11$

105 Delatycki MB, Danks A, Churchyard A, Zhou XP, Eng C. De novo germline PTEN mutation in a man with Lhermitte-Duclos disease which arose on the paternal chromosome and was transmitted to his child with polydactyly and Wormian bones. J Med Genet 2003;40:e92.

106 Zhou XP, Marsh DJ, Morrison CD, Chaudhury AR, Maxwell M, Reifenberger G, Eng C. Germline inactivation of PTEN and dysregulation of the phosphoinositol-3-kinase/Akt pathway cause human Lhermitte-Duclos disease in adults. Am J Hum Genet 2003;73:1191-8.

107 Sansal I, Sellers WR. The biology and clinical relevance of the PTEN tumor suppressor pathway. J Clin Oncol 2004;22:2954-63.

108 Cantley LC, Neel BG. New insights into tumor suppression: PTEN suppresses tumor formation by restraining the phosphoinositide 3-kinase/AKT pathway. Proc Natl Acad Sci U S A 1999;96:4240-5.

109 Maehama T, Dixon JE. The tumor suppressor, PTEN/MMACl, dephosphorylates the lipid second messenger, phosphatidylinositol 3,4,5trisphosphate. J Biol Chem 1998;273:13375-8.

110 Manning BD, Cantley LC. United at last: the tuberous sclerosis complex gene products connect the phosphoinositide 3-kinase/Akt pathway to mammalian target of rapamycin (mTOR) signaling. Biochem Soc Trans 2003;31(pt 3):573-8.

111 Pandolfi PP. Aberrant mRNA translation in cancer pathogenesis: an old concept revisited comes finally of age. Oncogene 2004;23:3134-7

112 Holland EC, Sonenberg N, Pandolfi PP, Thomas G. Signaling control of mRNA translation in cancer pathogenesis. Oncogene 2004;23:3138-44.

113 Fingar DC, Blenis J. Target of rapamycin (TOR): an integrator of nutrient and growth factor signals and coordinator of cell growth and cell cycle progression. Oncogene 2004;23:3151-71.

114 Rosenwald IB. The role of translation in neoplastic transformation from a pathologist's point of view. Oncogene 2004;23:3230-47.

115 Waite KA, Eng C. BMP2 exposure results in decreased PTEN protein degradation and increased PTEN levels. Hum Mol Genet 2003;12:679-84.

116 Mak BC, Takemaru KI, Kenerson HL, Moon RT, Yeung RS. The tuberinhamartin complex negatively regulates b-catenin signaling activity. J Biol Chem 2003;278:5947-51.

117 He XC, Zhang J, Tong WG, Tawfik O, Ross J, Scoville DH, Tian Q, Zeng X, $\mathrm{He} X$, Wiedemann LM, Mishina Y, Linheng L. BMP signaling inhibits intestinal stem cell self-renewal through suppression of Wnt-b-catenin signaling. Nat Genet 2004;36:1117-21.

118 van den Brink GR. Linking pathways in colorectal cancer. Nat Genet 2004;36:1038-9.

119 Vance KW, Goding CR. The transcription network regulating melanocyte development and melanoma. Pigment Cell Res 2004;17:318-25.

120 Saito H, Yasumoto KI, Takeda K, Takahashi K, Yamamoto H, Shibahara S. Microphthalmia-associated transcription factor in the Wnt signaling pathway. Pigment Cell Res 2003;16:261-5.

121 Larue L, Kumasaka M, Goding CR. $\beta$-Catenin in the melanocyte lineage. Pigment Cell Res 2003;16:312-7.

122 Yamaguchi Y, Itami S, Watabe H, Yasumoto KI, Abdel-Malek AZ, Kubo T, Rouzaud F, Tanemura A, Yoshikawa K, Hearing VJ. Mesenchymal-epithelial interactions in the skin: increased expression of dickkopfl by palmoplantar fibroblasts inhibits melanocyte growth and differentiation. J Cell Biol 2004; 165:275-85.

\section{1 th European Forum on Quality Improvement in Health Care}

26-28 April 2006, Prague, Czech Republic

For further information please go to: www.quality.bmipg.com

Book early to benefit from a discounted delegate rate 